\title{
Diet and dental development of three species of Roeboides (Characiformes: Characidae)
}

\author{
Gisele Caroline Novakowski, Rosemara Fugi and Norma Segatti Hahn
}

Lepidophagy has been recorded in various species of Roeboides. In this study we analyzed ontogenetic variation in diet and dental development of three Roeboides species ( $R$. paranensis, $R$. prognathus and $R$. microlepis). Roeboides paranensis consumed mainly insects, scales and microcrustaceans, and the smaller individuals $(<3.4 \mathrm{~cm}-\mathrm{SL})$ consumed mostly insects. Scale were only consumed by individuals greater than $3.4 \mathrm{~cm}$. Scales were the dominant item in the diet in all sizes of $R$. prognathus. The diet of $R$. microlepis was composed primarily of whole fishes, however, the smaller individuals $(<5.4 \mathrm{~cm})$ consumed only insects. During ontogeny, exterior migration of teeth in the mouth started at $3.7 \mathrm{~cm}$ in $R$. paranensis and $6.5 \mathrm{~cm}$ in R. microlepis. As body length increased more teeth migrated exteriorly. This leads to greater consumption of scales by three species. Roeboides prognathus appeared to be most specialized on scales, since they composed $80 \%$ of the diet, and was the species with the highest number of external teeth and the most developed.

O hábito de consumir escamas tem sido registrado para várias espécies de Roeboides. Neste estudo foram examinados a variação ontogenética na dieta e o desenvolvimento dentário de três espécies de Roeboides (R. paranensis, R. prognathus e R. microlepis). Roeboides paranensis consumiu insetos, escamas e microcrustáceos, sendo que os menores indivíduos $(<3,4 \mathrm{~cm}-\mathrm{CP})$ consumiram basicamente insetos, enquanto que escamas foram utilizadas apenas por indivíduos a partir de $3,4 \mathrm{~cm}$. Para $R$. prognathus, escamas constituiu-se no alimento dominante em todos os tamanhos analisados. A dieta de $R$. microlepis foi composta principalmente por peixes inteiros, no entanto, os menores indivíduos $(<5,4 \mathrm{~cm})$ consumiram somente insetos. Durante a ontogenia, a migração dos dentes para o exterior da boca se inicia a partir de 3,7 cm em R. paranensis e de $6,5 \mathrm{~cm}$ em R. microlepis. Com o crescimento dos indivíduos, mais dentes migram para fora da boca e tornam-se mais desenvolvidos, o que reflete um consumo maior de escamas para as três espécies. $R$. prognathus foi a mais especialista, visto que escamas representou cerca de $80 \%$ da dieta. Esta espécie também apresenta maior número de dentes externos e mais desenvolvidos que as outras espécies.

Key words: Roeboides, lepidophagy, freshwater, reservoir

\section{Introduction}

The genus Roeboides belongs to the family Characidae, and includes approximately twenty-two species. Its distribution ranges from southern Mexico and Central America to the La Plata basin, in South America (Lucena, 1998). These characids forage on scales of other fish, a behavior known as lepidophagy (Sazima \& Machado, 1982; Sazima, 1983; Peterson \& McIntyre, 1998; Hahn et al., 2000).

In addition to the characids, other freshwater and marine fish families are considered lepidophagous and forage similarly (Sazima, 1983). However, these families are unrelated, suggesting that this feeding behavior has arisen several times independently in the evolutionary history of the teleosts (Gerking, 1994). Several hypotheses have been proposed to explain the evolution of scales eating fish, and all suggest a trophic (e.g., ectoparasite removing, mucus-eating, modified forms of predation and piscivory and necrophagy) or social (e.g., aggressive intra and interspecific interaction during foraging) explanation (Sazima \& Uieda, 1980; Sazima \& Machado, 1982; Sazima, 1983).

Various morphological specializations are present in certain lepidophagous characoid species, however the only common characteristics in most of them are specialized dentition and jaw structure (Peterson \& McIntyre, 1998). Despite this characteristic, the degree of specialization of these attributes vary among species (Sazima, 1983; Peterson \& Winemiller, 1997; Peterson \& McIntyre, 1998) and may become more pronounced during ontogeny, as observed for Roeboides dayi, $R$. affinis and $R$. paranensis (Peterson \& Winemiller, 1997; Peterson \& McIntyre, 1998; Hahn et al., 2000).

In the area where our study was carried out, three species of Roeboides were caught: Roeboides paranensis (Pignalberi, 1975), Roeboides prognathus (Boulenger, 1895) and Roeboides

Núcleo de Pesquisas em Limnologia, Ictiologia e Aquicultura (Nupélia), Universidade Estadual de Maringá, Av. Colombo 5790, 9020 900 Maringá, PR, Brazil. e-mail: rfugi@ nupelia.uem.br. 
microlepis (Reinhardt, 1851). Information about diet and trophic morphology of these three species are scarce. To $R$. microlepis only 14 stomach contents had been analyzed (Sazima, 1983); to $R$. prognathus, Menezes \& Silva (1949) described the diet, and Sazima \& Machado (1982) described morphological characteristics of one young $(30 \mathrm{~mm})$ and one adult (76 mm), and to $R$. paranensis only one previous study had looked over the diet (Hahn et al., 2000).

Our objective was to evaluated diet and trophic morphology of these three species to answer the following questions: (i) what is the degree of specialization in the three species to lepidophagy? and (ii) is the dental and jaw development associated with diet?

Study Area. Our study was conducted at Manso reservoir (area $=427 \mathrm{~km}^{2}$ ) located in the State of Mato Grosso (Brazil) near to the Parque Nacional da Chapada dos Guimarães, and in Cuiabá River. The Manso River joins the Cuiabazinho River $80 \mathrm{~km}$ downstream the reservoir dam, forming the Cuiabá River that empties in to the Pantanal. Eighteen sites were sampled: one in the upstream and downstream reach of the Manso River, Manso Reservoir, the Cuiabá River and in two floodplain lagoons (Fig. 1).

\section{Material and Methods}

Fishes were collected monthly from March/2000 to February/2001 by gillnets ( 2.4 to $30.0 \mathrm{~cm}$ mesh), and seining

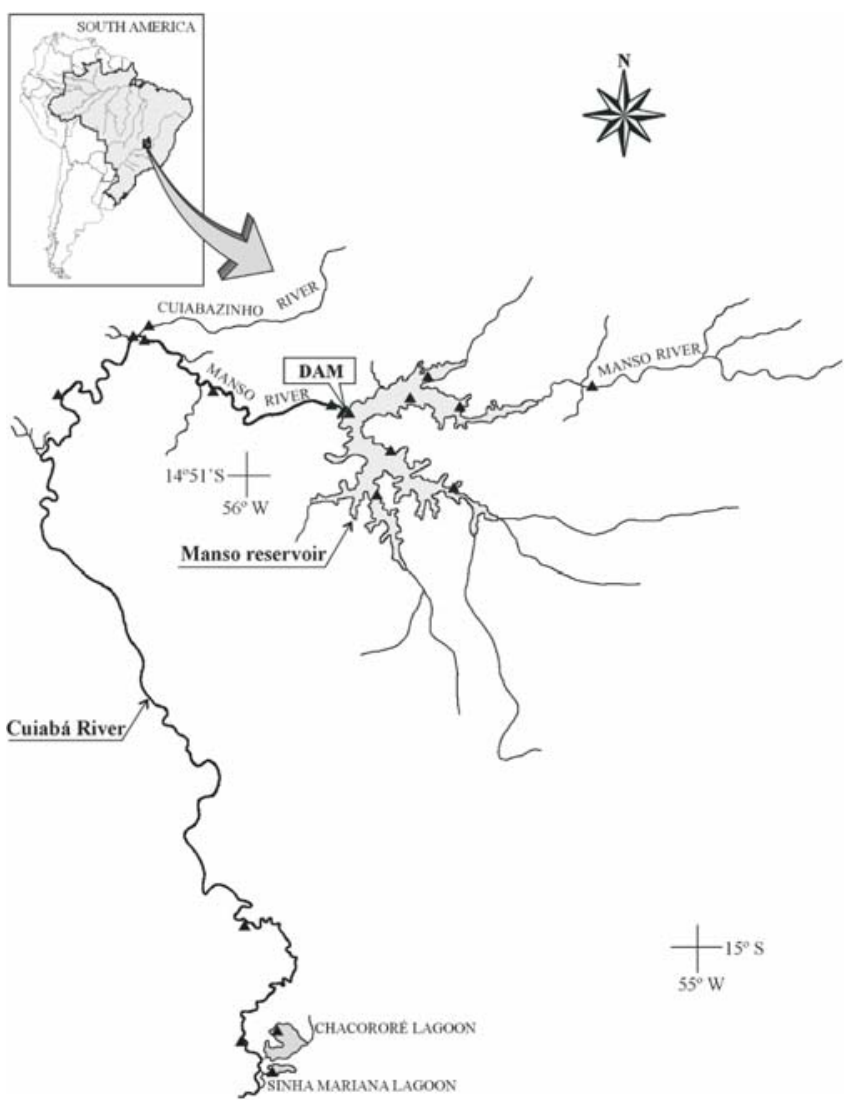

Fig. 1. Study area showing sampling locations $(\boldsymbol{\Delta})$.

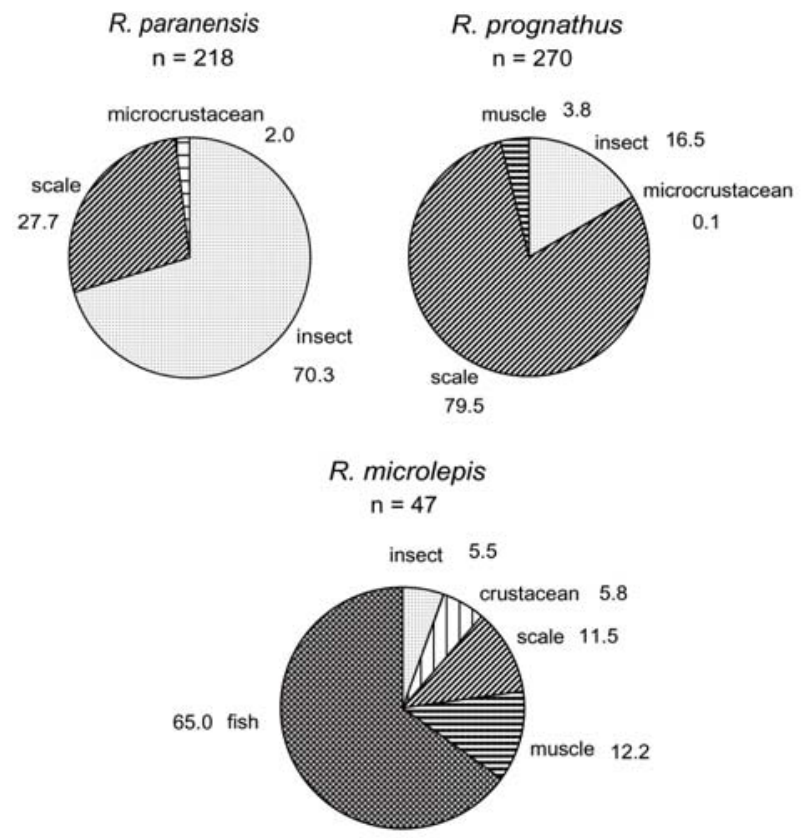

Fig. 2. Volumetric proportion of the food items in the diet of Roeboides species. ( $\mathrm{n}=$ number of analyzed stomachs).

( $1 \mathrm{~cm}$ mesh). Gill nets were set fov 24 hours and seining was conducted along the shoreline. All specimens were identified, measured and weighed, and their stomachs were excised and fixed immediately in $4 \%$ formaldehyde.

Roeboides microlepis was known until recently as Roeboides bonariensis (Steindachner, 1879), but Lucena (2003), in his taxonomic revision of the genus Roeboides, considered $R$. bonariensis a synonym of $R$. microlepis. Voucher specimens were deposited in the Ichthyological Collection of Núcleo de Pesquisas em Limnologia, Ictiologia e Aqüicultura (Nupélia): NUP 937 (19), 3129 (10), 921 (64 ), $930(20)$.

Stomach contents were analyzed by volumetric method (Hyslop, 1980), using graduated test tubes, and a counting glass plate (Hellawell \& Abel, 1971).

Ontogenetic variation (size classes based on the dental development) in the diet was determined using dental development, described to determine in which fish length (standard length - SL) the external teeth in the maxillary and premaxillary appear, and whether differences of number, form and size of these teeth are related to fish size. Ten specimens of different size classes of each species were taken at random for measurement of morphologic characterization. Dental development was described for three size classes of R. paranensis (2.0 to $7.9 \mathrm{~cm} \mathrm{SL}$ ) and R. prognathus (3.7 to $14.0 \mathrm{~cm} \mathrm{SL}$ ), and five size classes of R. microlepis ( 2.7 to $19.5 \mathrm{~cm}$ $\mathrm{SL})$. Teeth descriptions for $R$. prognathus were done only for individuals that already had external teeth.

\section{Results}

Diet. Diets among the three species varied. Roeboides paranensis primarily consumed insects (70\%) and scales (28\%), 
whereas $R$. prognathus ingested mostly scales $(79 \%)$ and insects (16\%). The diet of the R. microlepis was dominated by whole fishes $(65 \%)$, and others components, including fish muscles, scales, crustaceans and insects (Fig. 2).

The size class analysis showed that $R$. paranensis specimens smaller than $3.4 \mathrm{~cm}$ (SL) ate only insects (98.6\%) and microcrustaceans $(1.4 \%)$. Scales attained maximum consumption at $40 \%$ of the diet for larger size individuals ( $>5$ $\mathrm{cm})$. The diet of $R$. prognathus was composed predominantly by scales in all size classes, however, the proportion of this item gradually increased in largest individuals $(63 \%, 75 \%$ and $93 \%$, respectively, to the different size classes). Insects were the sole component (100\%) in the diet of R. microlepis smaller than $5.4 \mathrm{~cm}$. Individuals larger than $6.7 \mathrm{~cm}$ appeared to switch to whole fish. Scales attained maximum consumption at $68 \%$ of the diet for larger size individuals $(11.5-14.0 \mathrm{~cm})$. The diet of the largest individuals $(>14.5 \mathrm{~cm}$ ) was dominated by whole fishes (Fig. 3).
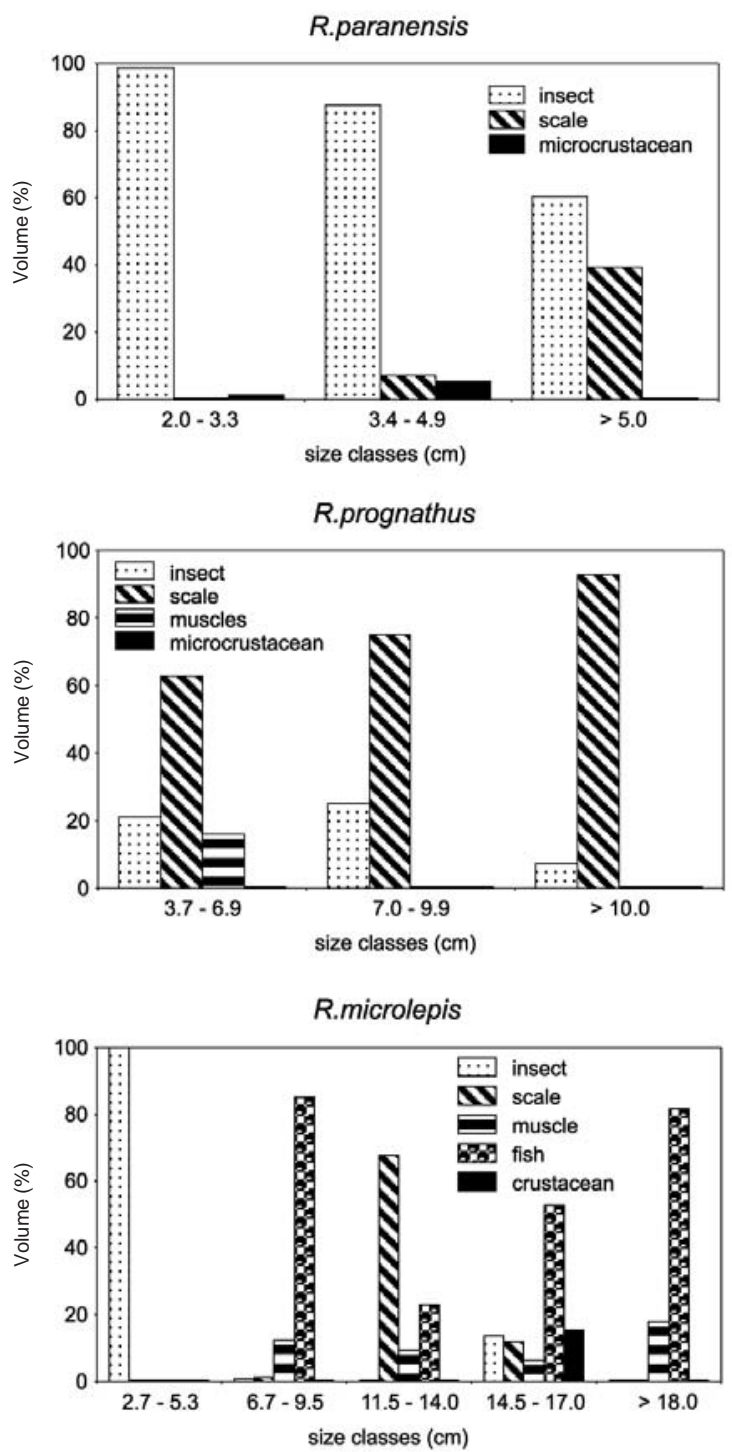

Fig. 3. Volumetric proportion of food items in the diet of different size classes of Roeboides species.
Dental development. External teeth were not found in small individuals ( $2.6 \mathrm{~cm} \mathrm{SL}$ ) of $R$. paranensis, but similar conical teeth in the maxillary, premaxillary and dentary were observed (Fig. 4). Individuals $3.7 \mathrm{~cm}$ in length (SL) exhibited external teeth, three conical in the premaxilla, two in the dentary and about six longitudinally distributed in the maxilla. The development of these teeth was gradual, and the superior became mammiliform (hypertrophied bases) before the inferior ones. The number of external teeth remained constant in all the largest individuals $(6.2 \mathrm{~cm} \mathrm{SL})$, however an increase in their size was observed. The mouth has terminal position.

External mammiliform teeth of different sizes in the premaxilla were present in R. prognathus ( $3.7 \mathrm{~cm} \mathrm{SL}$ ) (Fig. 5). The most developed teeth were the foremost premaxillary, and also, two mammiliform teeth of approximately the same size were present in the dentary. In the maxilla, about five conical teeth and one mammiliform were longitudinally located in the superior part. In larger individuals $(7.0 \mathrm{~cm} \mathrm{SL})$, new teeth had migrated to the external part of the premaxilla. The conical teeth became mammiliform in the maxilla. In the largest individuals $(11.0 \mathrm{~cm} \mathrm{SL})$ new teeth migrated to the external surface of maxilla and all external teeth were well developed. The mouth is subterminal and the upper jaw elongated forming a "snout" as the fish grew.

Small individuals ( $4.0 \mathrm{~cm} \mathrm{SL}$ ) of $R$. microlepis contained a series of conical teeth in the interior part of the mouth, similar to the premaxillary and dentary teeth (Fig. 6). Three teeth had migrated to the external surface of premaxilla and two to the dentary in smaller fishes $(6.5 \mathrm{~cm} \mathrm{SL})$. As the individuals of this species grew to $11.5 \mathrm{~cm} \mathrm{SL}$, two external maxillary teeth became visible. In larger individuals $(14.5 \mathrm{~cm} \mathrm{LS})$ a new tooth migrated to the maxilla. A new tooth had also migrated to the external surface of maxilla in the largest individuals $(18.0 \mathrm{~cm}$ $\mathrm{SL}$ ), as well as one to the external surface of premaxilla. The teeth of the largest sized fishes were hypertrophied. The mouth is wide and has terminal position.

\section{Discussion}

Scales can be found in fish stomach for several reasons; however, a true lepidophagous fish must contain scales in the stomach without the presence of bones, muscles or other tissues. For example, piscivorous frequently contain scales in their stomachs after soft tissues have been digested, and detritivorous fishes may consume scales that are in the substrate (Peterson \& McIntyre, 1998).

According to Peterson \& Winemiller (1997), fish scales are a nutritious, abundant and represent a renewable food resource. Given this inexhaustible feeding resource, several fish species, four freshwater and seven marine families (Gerking, 1994), have evolved specialized strategies, tactics, and changes in mouth structure (e.g., acquiring specialized teeth and jaw more appropriated to this type of predation) to better obtain this food.

Our results confirmed that the three species of Roeboides consumed scales differently. Roeboides paranensis was insectivorous-lepidophagous, because it consumed more insects than scales, which confirmed the results of Hahn et al. 

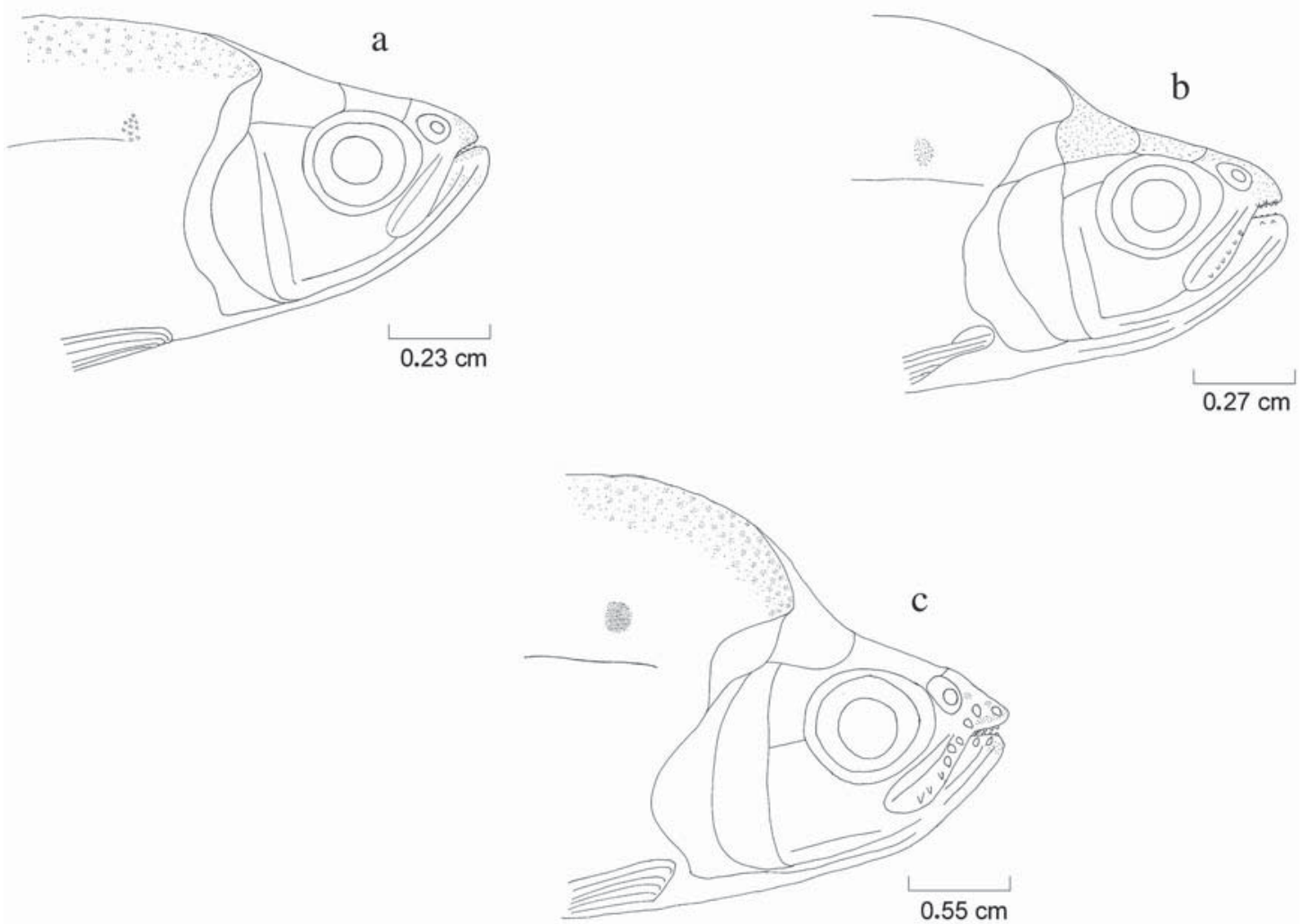

Fig. 4. Dental development of Roeboides paranensis at different SL sizes: $\mathrm{a}=2.6 \mathrm{~cm} ; \mathrm{b}=3.7 \mathrm{~cm} ; \mathrm{c}=6.2 \mathrm{~cm}$.
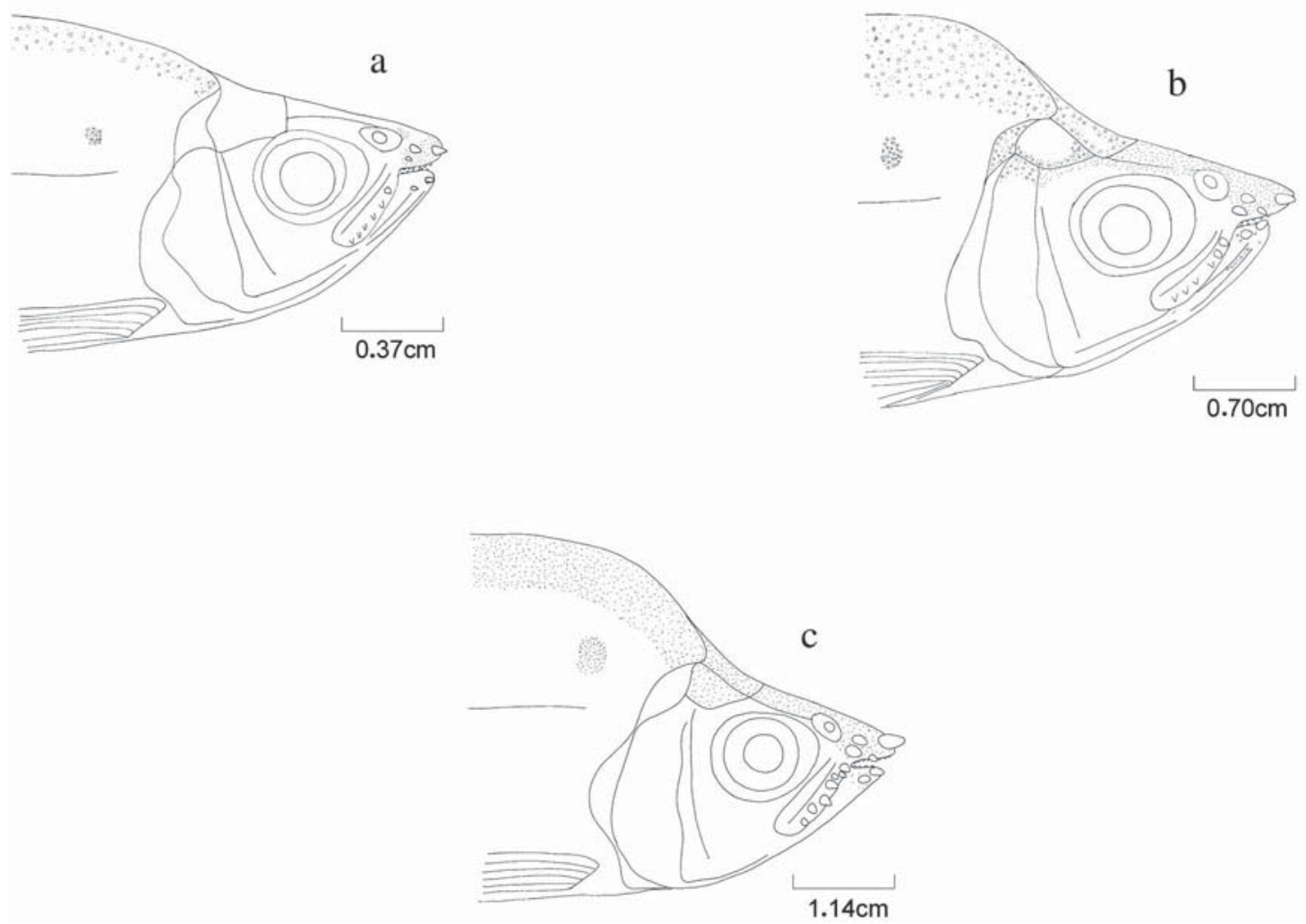

Fig. 5. Dental development of Roeboides prognathus at different SL sizes: $\mathrm{a}=3.7 \mathrm{~cm} ; \mathrm{b}=7.0 \mathrm{~cm} ; \mathrm{c}=11.0 \mathrm{~cm}$. 

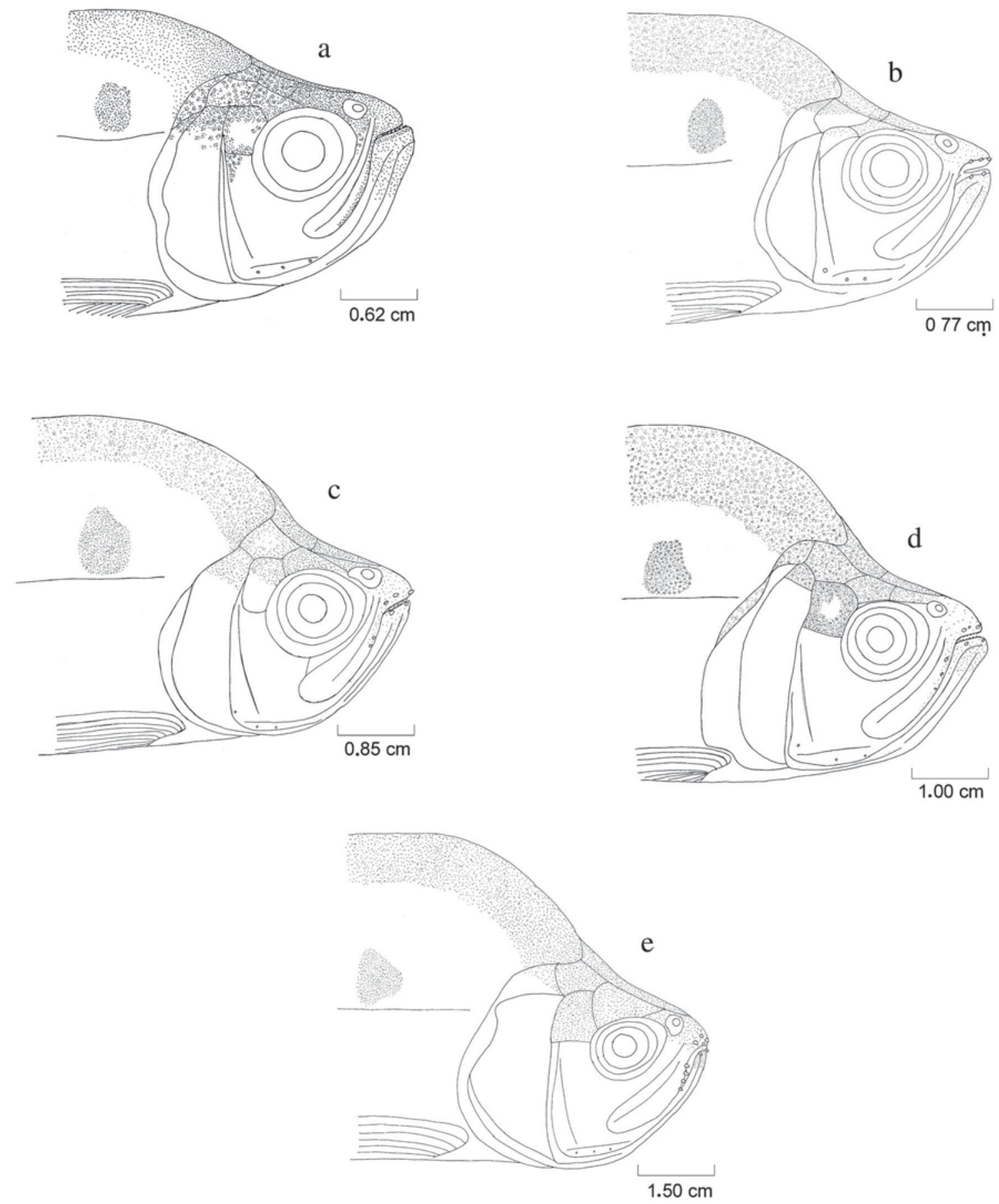

Fig. 6. Dental development of Roeboides microlepis at different SL sizes: $\mathrm{a}=4.0 \mathrm{~cm} ; \mathrm{b}=6.5 \mathrm{~cm} ; \mathrm{c}=11.5 \mathrm{~cm} ; \mathrm{d}=14.5 \mathrm{~cm} ; \mathrm{e}=18.0 \mathrm{~cm}$.

(2000) and Casatti et al. (2003). We found R. prognathus to be lepidophagous as verified by Sazima \& Machado (1982). Roeboides microlepis predated on whole fish, and we considered it piscivorous.

The migration of teeth to the external part of mouth seems to be the determinant factor of the feeding pattern of the three species we analyzed. This pattern was best noted in $R$. paranensis and $R$. microlepis, considering that absence of external teeth was found in fish consuming mostly insects, and then when fish shifted to a diet of scales the exteriorization of the teeth was present. It was not possible to follow the exteriorization of the teeth in $R$. prognathus since the smallest individuals collected already had external teeth.

Asymmetric grow of the jaws (upper jaw longer than lower jaw) may increase the ability of fish to consume scales (Sazima \& Machado, 1982; Peterson \& McIntyre, 1998), however we only observed this characteristic in $R$. prognathus. The elongation of the upper jaw has previously been observed in $R$. dayi and $R$. affinis and more pronounced in the $R$. affinis whose diet contained $100 \%$ scales (Peterson \& McIntyre, 1998). 
As body size increases, the external teeth of Roeboides tend to develop both, in number and size. Similarly we observed that along their development, the three species ate more scales, whose consumption increased from $7 \%$ to $40 \%$ in $R$. paranensis, from $62 \%$ to $93 \%$ in $R$. prognathus and from 1.4 to $68 \%$ in $R$. microlepis. After growing $R$. prognathus was the species with the highest number of external teeth and they appeared to be the most developed. According to Sazima \& Machado (1982), as individuals grow and their teeth get stronger and more external, the lepidophagous habit of several species of Roeboides becomes more pronounced.

Roeboides represents the only genus polytypic with lepidophagous feeding habits (Sazima, 1983); nevertheless, these species present different degrees of specialization for lepidophagy. This is especially evident when the relationship between morphology and the proportion of other food items, in addition to scales, are considered. Our data agreed with previous reports, suggesting that $R$. prognathus was the most specialized in foraging on scales (Sazima \& Machado, 1982). On the other hand, the diet of $R$. microlepis, dominated by whole fish, was very different from other species of Roeboides already studied (i.e., $R$. paranensis, $R$. dayi, $R$. affinis, $R$. guatemalensis and $R$. prognathus) that had a diet mainly composed of scales, insects and microcrustaceans (Menezes \& Silva, 1949; Sazima \& Machado 1982; Angermeier \& Karr, 1983; Peterson \& Winemiller, 1997; Peterson \& McIntyre, 1998; Hahn et al., 2000; Casatti et al., 2003). In addition, $R$. microlepis may be considered an exception among Roeboides, given that its length can reach $22.0 \mathrm{~cm}$ and its size is similar only to $R$. myersi $(18.0 \mathrm{~cm}$ ) (Lucena \& Menezes, 2003). Thus, the consumption of whole fishes by $R$. microlepis can be directly associated with its larger size, its larger mouth and robust characteristics.

Considering that the evolution of lepidophagy in fish had a trophic origin (Sazima \& Uieda, 1980; Sazima \& Machado, 1982; Sazima, 1983), the high consume of fishes by $R$. microlepis, and the presence of less developed external teeth, we suggest this species exhibits strong characteristics for piscivory. Its piscivorous nature is supported by its habit of taking pieces of muscles from prey. Thus, compared to $R$. prognathus, we infer that $R$. microlepis can be a facultative lepidophagous less adapted to the foraging on scales. According to Lucena (1998) the lepidophagous habit can be considered an additional synapomorphy to Roeboides; however, this habit can appear in different apomorphic states among the species of this genus.

\section{Acknowledgements}

We are grateful to Nupélia/UEM, FURNAS Centrais Elétricas SA. for logistic and financial support and Conselho Nacional de Desenvolvimento Científico e Tecnológico (CNPq) in terms of personal grants (CNPq procs. NSH: 350538/ 02-6). We thank to Sidinei M. Thomaz and Eric D. Dibble for reviewing the English manuscript.

\section{Literature Cited}

Angermeier, P. L. \& J. R. Karr. 1983. Fish communities along environmental gradients in a system of a tropical stream. Environmental Biology of Fishes, 9(2): 117-135.

Casatti, L., H. F. Mendes \& M. Ferreira. 2003. Aquatic macrophytes as feeding site for small fishes in the Rosana reservoir, Paranapanema river, Southeastern Brazil. Brazilian Journal of Biology, 63(2): 213-222.

Gerking, S. D. 1994. Feeding ecology of fish. New York, Academic Press. 416p.

Hahn, N. S., C. S. Pavanelli \& E. K. Okada. 2000. Dental Development and ontogenetic Diet Shifts of Roeboides paranensis (Osteichthyes, Characinae) in pools of the upper Rio Paraná floodplain (State of Paraná, Brazil). Revista Brasileira de Biologia, 60(1): 93-99.

Hellawell, J. \& Abel. 1971. A rapid volumetric method for the analysis of the food of fishes. Journal of Fish Biology, 3: 29-37.

Hyslop, E. M. S. 1980. Stomach contents analysis - a review of methods and their application. Journal of Fish Biology, 17:411-429.

Lucena, C. A. S. \& N. A. Menezes. 2003. Subfamily Characinae (Characins, Tetras). In: Reis, R. E., S. O. Kullander \& C. J. Ferraris (Eds). Pp. 200-208. Check list of the freshwater fishes of South and Central America. EDIPUCRS, Porto Alegre, $729 \mathrm{p}$.

Lucena, C. A. S. 1998. Relações filogenéticas e definição do gênero Roeboides, Günther (Ostariophysi; Characiformes; Characidae). Comunicações do Museu de Ciências e Tecnologia da PUCRS, Série Zoologia, 11: 19-59.

Lucena, C. A. S. 2003. Revisão taxonômica e relações filogenéticas das espécies de Roeboides grupo-microlepis (Ostariophysi, Characiformes, Characidae). Iheringia, 93(3): 283-308.

Menezes, R. S. \& S. L. O. Silva. 1949. Alimentação de cacunda Roeboides prognathus (Boulenger) da bacia do rio Parnaíba, Piauí. Revista Brasileira de Biologia, 9(2): 235-239.

Peterson, C. C. \& P. McIntyre. 1998. Ontogenetic diet shifts in Roeboides affinis with morphological comparisons. Environmental Biology of Fishes, 53: 105-110.

Peterson, C. C. \& K. O. Winemiller. 1997. Ontogenetic diet shifts and scale-eating in Roeboides dayi, a Neotropical characid. Environmental Biology of Fishes, 49: 111-118.

Sazima, I. 1983. Scale-eating in characoids and other fishes. Environmental Biology of Fishes, 9(2): 87-101.

Sazima, I. \& F. A. Machado. 1982. Hábitos e comportamento de Roeboides prognathus, um peixe lepidófago (Osteichthyes, Characoidei). Boletim de Zoologia da Universidade de São Paulo, 7:37-56.

Sazima, I. \& V. S. Uieda, 1980. Comportamento lepidofágico de Oligoplites saurus e registro de lepidofagia em $O$. palometa e $O$. saliens (Pisces, Carangidae). Revista Brasileira de Biologia, 40(4): 701-710.

Received June 2004

Accepted September 2004 